\title{
CUNARD AND THE NORTH ATLANTIC I840-I973
}


By the same author

MR. GLADSTONE AT THE BOARD OF TRADE

BLUE FUNNEL: A HISTORY OF ALFRED HOLT \& COMPANY 1865-I914 SHIPPING ENTERPRISE AND MANAGEMENT LIVERPOOL AND THE MERSEY: AN ECONOMIC HISTORY OF A PORT FAR EASTERN TRADE 1860-I9I4 (with others)

A NEW PROSPECT OF ECONOMICS

THE SENIOR: JOHN SAMUEL SWIRE I824-I898 (with S. Marriner) 


\section{CUNARD \\ AND THE \\ NORTH ATLANTIC \\ I840 - I973}

\section{$A$ History of Shipping and Financial Management}

by

FRANCIS E. HYDE

Chaddock Professor of Economic History in the University of Liverpool

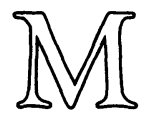


- Francis E. Hyde 1975

Softcover reprint of the hardcover 1st edition 1975

All rights reserved. No part of this publication may be reproduced or transmitted, in any form or by any means, without permission.

\section{First published 1975 by \\ THE MACMILLAN PRESS LTD}

London and Basingstoke

Associated companies in New York

Dublin Melbourne Johannesburg and Madras

ISBN 978-1-349-02392-9 ISBN 978-1-349-02390-5 (eBook)

DOI 10.1007/978-1-349-02390-5 
To

my wife

ANN ELIZABETH 


\section{Contents}

List of Plates

xii

Preface

CHAPTER 1 Foundation, Capital Structure and Control xvii of the Company 1840-80

I Samuel Cunard: early business enterprise: securing the mail and shipbuilding contracts

II The foundation of the British and North American Royal Mail Steam Packet Company: the Burns and MacIver brothers: the original partners and the new co-partnership contract

III Burns and MacIver family backgrounds: the Mediterranean and Levant trades: control and the division of capital in the Atlantic and Mediterranean companies

IV Incorporation and the Agreement of 1880: role of the managing agents and reorganisation of capital

CHAPTER 2 Men, Ships and Mails 1840-80

I The inauguration of the Atlantic service: improvement in design, power and size of ships

II Mail contracts and competition

III The Collins line and intensification of competition 
IV Secret agreement between Cunard and the Collins line: the fixing of rates and pooling of earnings

V Charles MacIver's management of the ships

VI John Burns and the new mail contract

VII Financial progress and growth i 840-80: the assumption of control in new hands

CHAPTER 3 Cunard and the Emigrant Trade 1860-1900

I Liverpool as focal point for the emigrant trade: competition between Liverpool based shipping companies: fluctuations in the trade

II Cunard's participation in the emigrant trade and government involvement in the maintenance of services

III Changes in the direction of the trade: efficiency and goodwill of agents

IV Relative profitability of the trade

CHAPTER 4 Cunard and North Atlantic Conferences 1860-1914

I The growth of competition and the need for agreement

II The Liverpool Steamship Conference: controversy on rates for slow and fast ships: the depression 1874-8: growing strength of German lines

III The use of the Conference system by the German lines: Conference agreements and rate wars: Cunard leaves the Conference: the Atlantic Pool

IV Alliance of Morgan Combine and German shipping companies: the impact of this alliance on Cunard: the Frankfurt Conference and the Continental Pool: the 1908 Agreement: attempt by United States to break Conference agreements 
I The new shipbuilding policy: resignation of MacIver brothers

II The building programme and trade fluctuations: Admiralty agreements: fluctuations in costs and receipts: the problem of large ships at Liverpool

III Cunard's earning capacity and allocation of resources: purchase of Thomson line

IV The Morgan Combine and the I903 Agreement

V The return on capital

CHAPTER 6 War, Peace and Depression 1914-34

I Cunard's contribution to the war effort

II Post-war difficulties: amalgamation and expansion

III United States immigration policy and post-war shipbuilding programme

IV Fluctuations in receipts and costs

V Cunard's attempts to increase revenue and reduce costs

VI Assessment of managerial efficiency

CHAPTER 7 No. 534 and the Formation of Cunard White Star Limited

I Events leading to merger

II White Star negotiations

III No. 534 and the Government: hopes of a two-ship express service

IV Growing competition and the need for action: the Government and the tripartite agreement

V The launching of Cunard White Star Ltd: Queen Mary in service: final analysis 
CHAPTER 8 North Atlantic Conferences 1921-39

I Agreements F.I., S.I., T.I.: fluctuations in membership: maintenance of security in home ports

II Disagreements on rates: rebuilding of rate schedules: conversion of ships' classes

III Introduction of tourist class and disagreements arising

IV Share of traffic to each line

V The operation of the Freight Conference

VI Advantage of conference membership: value of cabin class schedule: cooperation between Cunard and White Star

CHAPTER 9 Advent of War and Survival 1935-45

I Changes in capital structure

II Efforts to increase revenue and reduce costs: the new Mauretania and Queen Elizabeth: the meeting of financial obligations: the problem of replacing war losses

III Requisition and war service: Queen Mary and Curaçoa

IV Cunard's growing awareness of competition from air travel

V The death of Sir Percy Bates and the effectiveness of management in peace and war

CHAPTER 10 Cunard and the North Atlantic 1946-73

I The change-over from war to peace

II The phasing out of Cunard White Star Ltd: increase in Cunard Company's capital

III Effects of penal fiscal legislation: plans for new Queen

IV Cunard's participation in transatlantic air travel 
V Rationalisation and entry into container services: the financing of the new Queen: passenger shipping and the leisure industry

VI Cunard and Trafalgar House Investments Ltd

VII Conclusion

Appendix

Notes

Index of Persons 


\section{List of Plates}

between pages 172 and 173

\section{I, 2 Samuel Cunard}

3 Charles MacIver (by permission of the Walker Art Gallery, Liverpool)

4 George Burns

5 Britannia

6 Persia

7 John Burns

8 Cunard advertisement

9 Sir Alfred Booth

Io The first Mauretania

I I Sir Thomas Royden

12 Queen Mary

I 3 Sir Percy Bates

I4 Queen Elizabeth as a troopship

is Queen Elizabeth 2

I6 Queen Elizabeth on fire (by permission of Keystone Press Agency $L t d$ ) 


\section{Preface}

Students of maritime history have always been exercised by the fact that no definitive full-scale history of The Cunard Steam Ship Company has been published. In order to obtain information about the activities of this Company one has had to glean from a wide range of sources concerned generally with the history of British shipping. Though some of these sources have been, and still are, most valuable in providing perspectives, they do not give a continuous account of Cunard's widespread interests nor an appraisal of the forceful characters of the successive generations of men who built up and directed the use of the Company's resources. Furthermore, very little of the information about the Company had been drawn from an overall examination of the Cunard archives. It was, therefore, as an endeavour to fill in the many gaps in Cunard's long history that the author of this volume was given permission by the Cunard Board (and subsequently by Trafalgar House Investments Ltd) to make free use of the Cunard archives and to publish a business history of the Company.

Of the published works referred to in the previous paragraph the most important references to Cunard are to be found in Volume 4 of W. S. Lindsay, History of Merchant Shipping and Ancient Commerce (1876); A. J. Maginnis, The Atlantic Ferry (1892); Sir William Forwood, Reminiscences of a Liverpool Shipowner (1920); F. C. Bowen, A Century of Atlantic Travel (1930); F. L. Babcock, Spanning the Atlantic (193I); Sir Westcott Abell, The Safe Sea (1932); R. L. Hadfield, Sea-Toll of our Time (1935); Humfrey Jordan, Mauretania (1936); E. R. Benstead, Atlantic Ferry (1936); Boyd Cable, $A$ Hundred Year History of the P. \& O. (1937); David B. Tyler, Steam Conquers the Atlantic (1939); Commander C. R. Vernon Gibbs, Passenger Liners of the Western Ocean (1952); N. R. P. Bonsor, North Atlantic Seaway (1956); D. Lobley, The Cunarders 


\section{Preface}

(1969); K. C. Barnaby, Some Ship Disasters and Their Causes (1970); J. M. Brinnin, The Sway of the Grand Saloon (1971); Colin Simpson, Lusitania (1972).

It is perhaps not generally known that on several occasions the Company commissioned the writing of an official history. As early as I 886, a privately published history of The Cunard Steam Ship Company was extracted from The Illustrated Naval and Military Magazine. In the late I930s, Captain Taprell Dorling (known by the pen-name 'Taffrail') was asked to write a complete history of the Company. The manuscript was largely concerned with specifications of ships and ignored the commercial aspects of the Company's business. Secondly, Mr Tom Hughes prepared a manuscript covering the Company's history from I 839 to I906; the manuscript was never completed. Thirdly, Mr Charles Graves, brother of Robert Graves, wrote a history of the Company's achievements during the Second World War. Though this was actually printed by an American publisher, it was not circulated and the whole edition was eventually pulped. Finally, Henry Eaves, a Secretary in the Company, produced an 800-page typescript giving a yearby-year account of the Company's history from i 840 to 1957. The author made full use of the annual reports and accounts and the work as a whole contains much valuable information not only about the ships but also of the use of resources by successive boards of directors and chairmen. Though this typescript could not be published in the chronological form in which it had been written, one must pay tribute to the vast amount of research involved in its compilation; it is a mine of information on almost every aspect of the Company's affairs.

As will be seen from the following pages, the story of Cunard's endeavour on the North Atlantic is highly complex and difficult of interpretation. For this reason the book has been sectionalised in order to give comprehension to the various threads of development in both policy and action which, when woven together, make up patterns on a wide historical canvas. The whole picture thus presented is one of sustained struggle in an attempt to build and manage ships economically, to sustain competitive advantage over both British and foreign shipping companies, to engage in a growing partnership with government for the safeguarding of mercantile supremacy in time of national emergency and to make effective the use of resources in the service of the ocean traveller. 


\section{Preface}

The terms of reference governing the writing of this book were reasonably flexible, though stress was laid on the need to investigate the changing scope of successive managements in the accumulation and use of resources and in the solution of problems inherent in the nature of a great shipping enterprise. In a strict sense, this book is not a business history, though the subject matter is largely concerned with financial and business management. In this context, it has not been possible or relevant to give details of the performance of individual ships in Cunard's fleet. To those readers who are interested in such details, therefore, the author expresses his regret and hopes that other information about the management of the Company may act as compensation. As far as possible, within the terms of reference, this book is definitive in compass; to have written both a comprehensive and definitive study of all Cunard's activities over a period of 130 years would have required the production of several large volumes. For those who are interested in aspects of the Company's history not fully covered in this volume, reference should be made to the Cunard archives which, through the generosity of the Cunard Board and that of Trafalgar House Investments Ltd, have now been put on loan in the library of the University of Liverpool. The access thus provided will stimulate further research not only into the history of one of Britain's internationally famous passenger steamship companies, but also into the more comprehensive elucidation of maritime history as a whole during the course of the last century.

University of Liverpool

Francis E. Hyde

March 1975 


\section{Acknowledgements}

During the writing of this book the author has received much help and kindly criticism from a large number of persons interested in the history of The Cunard Steam Ship Company. Sir Basil Smallpeice, as Chairman of Cunard, initiated the project and made it possible with the permission of the Cunard Board for a free examination of Cunard archives. These archives, as stated in the Preface, through the generosity of Trafalgar House Investments Ltd, have now been placed on permanent loan in the Harold Cohen Library of the University of Liverpool. In pursuance of continuity in the writing of this book, the author is most grateful to Mr Victor Matthews, Chairman, and to Mr Norman Thompson, Managing Director of The Cunard Steam Ship Co. Ltd, for their agreement to proceed to publication. To the late Mrs Lois Rae, granddaughter of Charles MacIver, the author owes a special debt of gratitude for free access to many important Maclver papers in her possession and for her most generous action in donating these papers to the University of Liverpool. This second gift of papers, complementary to the vast bulk of the Cunard archives, will help future historians in their elucidation of the Company's history before 1880 . Such benefactions ensure that future research into the maritime history of this Company may be carried on in the port of Cunard's origin and service. It was through the kindness of $\mathrm{Mr} \mathrm{W}$. H. P. Piper of the Royal Insurance Co., Liverpool that the author was put in touch with Mrs Rae.

The author has received the greatest possible help from past and present members of the Cunard Company, including Mr F. J. Whitworth, former Managing Director of the Cunard Line, Mr Frank Leach, Secretary to the Cunard Board, Mr H. M. Goulden, former Secretary to The Cunard Steam Ship Co. Ltd, Mr W. D. McKinlay, former Assistant Accountant to The Cunard Steam 


\section{Acknowledgements}

Ship Co. Ltd, Mr Kendrick Williams, Assistant Secretary, Mr J. G. Dalton, Operations Manager, Cunard Line Ltd, Southampton and Mr D. K. J. Conway, Chairman, North Atlantic Westbound Freight Association. They not only made all existing Cunard records available but gave much valuable assistance in the discovery of complementary sources of information. Mr Ivor Jones, formerly of the General Manager's Office and, later, Property Manager for Cunard, who was asked by the Board to help the author in the task of collecting relevant information from the vast bulk of archives, has been energetic in his quest. The author acknowledges his willing service, especially for the many long hours of labour in his search for information in the Board Minutes and in the mass of paper stored in the vaults of the Cunard Building, Liverpool. He was also responsible for the compilation of the fleet lists contained in the Appendix. Mr R. Leslie Adam of Hill, Dickinson and Co., the Company's solicitors, placed his unrivalled knowledge of maritime history and, in particular, his great experience of the financial management of the Company, freely at the author's disposal. The book has been given a greater accuracy as a result of his careful reading of the first six chapters and his subsequent comments on style and presentation.

Most large companies have their own historians. In the case of Cunard, one must not overlook Henry Eaves, a former Secretary. As already stated, his unpublished history of Cunard, drawn largely from Board Minutes and Chairmens' Reports, has been of considerable assistance in the provision of source material. It is, however, to Mr T. Laird, former General Manager of the Company, that the author owes his greatest debt of gratitude. His wide knowledge of Cunard's history and his critical appraisal of events have been constantly made available to the author; to him should most properly be ascribed the title of Cunard's historian.

$\mathrm{Mr}$ Laird spent the whole of his working life with Cunard. His loyalty to management (of which he ultimately became a part) to staff and employees, is evident in all his pronouncements. Yet he is not uncritical of Cunard's failings. His work with the Company covered the time of peak achievement during the inter-war years, the Second World War and the post-war period of some twenty years up to I965. During this long period he acquired an unrivalled knowledge of ships and their management. He became an expert in Conference matters and, during his term of office as General 


\section{Acknowledgements}

Manager, he was responsible along with many of his colleagues for the reorganisation of the Company, and the initial planning of Queen Elizabeth 2. He witnessed the decline of the Company's fortunes after 1957 and was not unaware of the causes. His experience and knowledge of those unhappy years are reflected in the final chapter of this book, though it must be emphasised that all the opinions expressed are solely those of the author. Mr Laird has read the whole of this book in successive drafts. It is hoped that, in its final form, it will not disappoint one who has for so long been a participant in shaping the Company's history.

The author wishes to express his thanks to the late $\mathrm{Mr} \mathrm{A}$. Douglas Lobley who, having read the drafts of some of the early chapters, presented the author with a wide range of comments and information on Britain's maritime development in the nineteenth century; to Mr Basil Greenhill, Director of the National Maritime Museum, Greenwich, for information about Samuel Cunard's early shipping activities; to Mr Mungo Conacher, formerly Chief General Manager of Martin's Bank for permission to use records relating to the Company's account with that Bank; to Mr P. Cotterell, now of the Department of Economic History in the University of Leicester, for extracts from the Glyn, Mills papers; to $\mathrm{Mr} \mathrm{B}$. L. Anderson of the Department of Economic History in the University of Liverpool for information relating to Cunard's insurance policy during the 1870 and to drawing the author's attention to John Burns's evidence before the Royal Commission on Unseaworthy Ships; to Miss Pauline Round, Department of Geography in the University of Liverpool for checking contemporary maps of New Brunswick; to members of the photographic section in the Department of Geography for the excellent reproduction of plates in this volume and to $\mathrm{Mr} \mathrm{R}$. Bastin for permission to use material from his M.A. thesis on Cunard and the Emigrant Trade I 860-I900.

The subject matter of Cunard's history is wide-ranging, touching as it does on spheres of interest in both governmental and international affairs as well as those concerned with rival shipping companies. In this context the author has been most fortunate in receiving letters and documents from numerous correspondents all over the world. In particular, he wishes to thank Mrs Eleanor Sparks Davison, daughter of Sir Ashley Sparks, Cunard's Resident Director in New York, for letters, telegrams 


\section{Acknowledgements}

and newspaper cuttings relating to her father's important service to the Company; to $\mathrm{Mr}$ E. Reford for information about his firm's long-standing connection with Cunard; to Commander $\mathrm{H}$. E. Morison - whose great-aunt, Mary Ann Morison, married Charles MacIver - for information about his career with Cunard; to Mr Patrick Howarth, Public Relations Officer to the R.N.L.I., for information about Cunard's interest in the Life-Boat Service and documents relating to the provision of a life-boat by the Cunard Company in 1930 and to Miss Frances Gutteridge for sending to the author a series of original illustrations of past Cunard and White Star ships.

The onerous task of typing the text, checking the footnotes and preparing the final copy for publication was efficiently undertaken by Mrs J. Irons. No words can adequately express the author's gratitude to his wife, Ann Elizabeth, for the patience which she showed during the writing of the book, to the willingness which she always gave to the reading of successive drafts and for the encouragement which was forthcoming whenever difficulties arose. It is to her that the book is justly dedicated. 